\title{
LA CIUDAD DESDE EL ACTIVISMO \\ Y LA CULTURA VISUAL: HACIA UNA MIRADA URBANA DEL COLECTIVO DOCENTE
}

The City from the Perspective of Activism and Visual Culture: Generating an Urban Vision among Teachers

\section{Ricard Huerta \\ Profesor del Departamento de Didáctica de la Expresión Musical, Plástica y Corporal - Universitat de València}

RESUMEN: Considero de máxima relevancia la creación de elementos propios del colectivo docente. El conjunto del profesorado se encuentra muy dividido por instancias, legislaciones y situaciones particulares. Conscientes de las diferencias que nos separan, deberíamos favorecer lugares comunes para sentirnos más unidos, evitando así la distancia debilitadora que existe entre las realidades del profesorado de infantil, primaria, secundaria y universidad. Desde los estudios culturales y la cultura visual se vienen elaborando estrategias que pueden resultar eficaces para generar nuevos entornos comunes, espacios donde podamos compartir elementos y problemáticas que nos afecten. Construir una mirada urbana propia del colectivo docente pasa por revelar las afinidades que nos definen. Para iniciar esta labor fomentamos un encuentro con la mirada particular de los y las docentes. Llevamos años recogiendo opiniones e imágenes a través de las cuales se pueda conocer mejor cómo ve y de qué manera entiende su ciudad el profesorado que la habita. A partir de fotografías y entrevistas tejemos una red de convergencias, analizando aquellos elementos que más motivan al profesorado de cada lugar. Intentamos conocer mediante textos e imágenes cuál es la mirada que vierte el colectivo docente hacia su ciudad, y de qué modo se intenta mejorar dicha realidad vivida.

Palabras clave: profesorado, ciudad, cultura visual, activismo, educación artística. 
RESUM: Considere de màxima rellevància la creació d'elements propis del col·lectiu docent. El conjunt del professorat es troba molt dividit per instàncies, legislacions i situacions particulars. Conscients de les diferències que ens separen, hauríem d'afavorir llocs comuns per a sentir-nos més units, s'evitaria així la distància afeblidora que hi ha entre les realitats del professorat d'infantil, primària, secundària i universitat. Des dels estudis culturals i la cultura visual s'elaboren estratègies que poden resultar eficaces per a generar nous entorns comuns, espais en els quals puguem compartir elements i problemàtiques que ens afecten. Construir una mirada urbana pròpia del col-lectiu docent implica revelar les afinitats que ens defineixen. Per a encetar aquesta tasca fomentem una trobada amb la mirada particular dels docents i de les docents. $\mathrm{Fa}$ anys que recollim opinions i imatges a través de les quals es puga conèixer millor com veu i de quina manera entén la seua ciutat el professorat que l'habita. A partir de fotografies i entrevistes teixim una xarxa de convergències, analitzant aquells elements que més motiven el professorat de cada lloc. Intentem conèixer mitjançant textos $i$ imatges quina és la mirada que projecta el col·lectiu docent cap a la seua ciutat, i de quina manera s'hi intenta millorar aquesta realitat viscuda.

Paraules Clau: professorat, ciutat, cultura visual, activisme, educació artística.

ABSTRACT: In my view it is important to create elements that belong to teachers. As a group, teachers are divided by procedures, laws and specific situations. Aware of the differences that separate us, we should encourage the creation of common spaces where we can feel more united. We must bridge the gaps between teachers at all levels: nursery school, primary school, secondary school and university. Cultural studies, and more specifically, visual culture, are developing effective strategies for generating common environments and transit sites, areas where we can all share issues that affect us. Building an urban vision that belongs to teachers means uncovering the affinities that define us. This endeavour begins with a proposal for an encounter with teachers' specific visions. Over many years we have gathered opinions and images to learn more about how teachers understand their city. Using photographs and interviews we analyse the elements that most motivate teachers in each place. We try to discover, through texts and images, teachers' visions 
of their cities, and how the reality they experience can be improved. This paper reflects the opinions of Uruguayan, Argentine, Chilean, Peruvian and Spanish teachers.

KEYWORDs: teachers, city, visual culture, activism, arts education.

\section{Indagando en la posibilidad de una mirada docente hacia el entorno urbano}

$A \begin{aligned} & 1 \text { indagar en la cultura de la ciudad asumimos una reivindicación que es } \\ & \text { compartida por numerosos profesionales de la educación. Somos cons- }\end{aligned}$ cientes de que el modelo que definimos como urbano se sustenta en una serie de características comunes que se vienen definiendo desde la Edad Media en la cultura occidental. Lo urbano provoca en nosotros un gran interés, ya que participamos de esta realidad humana, al tratarse de una cuestión eminentemente cultural y económica (Belil, Borja y Corti, 2012). Nuestra capacidad crítica genera asimismo un deseo de análisis y prospección que compartimos con otros colectivos profesionales (artistas, antropólogos, sociólogos). Pero si bien los arquitectos, los urbanistas (Lynch, 1998), los literatos (Leopardi, 2014) o los historiadores (Braudel, 1979) han sabido utilizar y definir el entorno urbano en función de sus intereses, lo cierto es que desde el colectivo docente no hemos generado todavía un ámbito propio de observación y diálogo con la ciudad. Sí que se ha desarrollado el concepto de «ciudad educadora», pero no es este el entramado al que ahora nos referimos. Reflexionar sobre dicha cuestión nos lleva a tomar un posicionamiento activo (e incluso me atrevería a decir activista) que nos permita acercarnos sin complejos al fascinante aparato cultural, político y económico que incluye todo aquello relativo a la experiencia humana vivida por el profesorado en la ciudad (Huerta, 2015 a).

A lo largo de una trayectoria que supone la experiencia de tres décadas como educador, detecto que mis intereses siempre han basculado a partir de 
dos estrategias que se combinan y se entretejen: las identidades y los patrimonios. Al plantear miradas convergentes hacia las personas y hacia los lugares, esta doble perspectiva consigue agrupar lo material y lo espiritual, lo tangible y lo intangible, las ideas y sus derivaciones, lo individual y lo colectivo. Asumo mi adscripción al colectivo docente como profesional de la educación, lo cual me inscribe (y me describe) en tanto que individuo perteneciente a un grupo humano en el que coincidimos todas las personas que nos dedicamos a la educación (Huerta, 2010a). Esta visión amplia permite incorporar en el mismo conjunto humano a maestros y maestras de educación infantil y primaria, al profesorado de secundaria y universitario, e incluso a todas aquellas personas que están trabajando de forma profesional en entornos de educación no formal. Como educadores generamos unas necesidades concretas. Nos unen muchas más cuestiones de las que nos puedan separar (Dewey, 1969). Al fin y al cabo, formamos parte activa de una compleja y enriquecedora maraña de circunstancias, además de compartir similares problemáticas, intereses y expectativas (Donaire, 2012). Está en nuestras manos una parte importante de lo que puede ser el futuro de la sociedad, ya que trabajamos con las generaciones más jóvenes, lo cual supone estar siempre muy pendiente del factor humano, algo que conlleva el trato directo con el alumnado (Aguirre, 2004).

Como educadores nos movemos en un escenario donde se establecen tramas que conducen a la identidad de los docentes, lo cual debería promover entre nosotros un verdadero propósito de análisis, ya que al generar sinergias vamos construyendo nuestras propias características como colectivo (Giroux, 2013). Se trata de establecer pautas mediante las cuales podamos acotar, definir y reivindicar un escenario propio, entendiendo que dicho escenario suele ser precisamente el entorno urbano. En la ciudad ocurren cosas. Se trata de un entorno privilegiado muy propicio para las acciones y los cambios. Por tanto, es en la ciudad donde se transforman los conceptos y donde nacen nuevas perspectivas. Participar del futuro incentivando las mejoras es una obligación y un reto para el colectivo docente, teniendo en cuenta que el profesorado constituye un buen ejemplo de gremio responsable con espíritu crítico (Giroux, 1990). Desde esta perspectiva implicada, y atendiendo a nuestra responsabilidad social, como docentes estamos capacitados para gestionar una 
nueva mirada hacia lo urbano, desde una visión amplia y respetuosa, capaz de aceptar la diversidad y los cambios constantes.

\section{Estrategias metodológicas desde la cultura visual}

Al ocuparnos de la realidad urbana tal y como la vive el conjunto del profesorado tratamos de valorar o constatar si realmente existe una mirada particular y propia del colectivo docente hacia lo que significa la ciudad como entorno privilegiado. Para ello utilizamos diferentes planteamientos de análisis, combinando aspectos metodológicos diversos, básicamente de corte cualitativo. Trabajamos con estrategias propias de los estudios culturales, especialmente desde la cultura visual (Hernández, 2000). La participación del profesorado como grupo implicado resultará, por tanto, fundamental. Abordamos la cuestión solicitándoles que nos relaten su visión de la ciudad, para lo cual utilizamos tanto textos y comentarios verbales (entrevistas y cuestionarios personales) como imágenes (fotografías realizadas por el propio profesorado). Además de plantearles preguntas y de solicitar que realicen fotografías, también gestionamos acciones performativas en las cuales el profesorado participa activamente, con lo cual logramos un grado de implicación mucho mayor. Este sistema permite acercarnos a las opiniones del profesorado, tanto a través de sus respuestas como mediante su participación directa en actividades de índole artística y performática. Posteriormente se seleccionan las imágenes y se establece un criterio de valoración de las respuestas a los cuestionarios. Todo ello es posible gracias a la utilización de acciones puntuales ambientadas en las artografías (Irwin, 2013). De este modo el profesorado participa en directo en una serie de acciones artográficas (Irwin \& O'Donoghue, 2012), lo cual permite un notable acercamiento a sus postulados, ya que se alcanza un grado de confianza mucho mayor. El concepto de «artografía» parte de las tres iniciales de la palabra, de modo que A es artist, $\mathrm{R}$ es researcher, y $\mathrm{T}$ es teacher. Se pretende comprender a quien educa en las facetas unidas de artista, investigador y docente. Mediante las acciones participativas estimulamos la reflexión, para posteriormente recoger sus opiniones de los cuestionarios y las fotografías que han hecho los docentes sobre su ciudad. En lo referido a la realización de imágenes damos paso a la metodología conocida como Arts Based Research, un planteamiento de 
investigación educativa basada en las artes. Recogemos toda esta documentación en los diferentes países donde hemos planteado este esquema de trabajo. Posteriormente contrastamos los datos de cada una de las ciudades donde se han realizado las acciones, escuchando voces diferentes y geográficamente distantes, pero que todas responden a las opiniones de docentes de todos los niveles educativos, a partir de entrevistas semiestructuradas, recabando la información y analizándola a partir de metodologías eminentemente cualitativas, estudios de caso y narrativas personales.

Otros elementos que incorporamos a nuestra investigación sobre la mirada urbana de los docentes surgen de las diferentes disciplinas artísticas, especialmente de la literatura y el cine. Nuestro acercamiento hacia lo urbano cuenta con el flujo constante que desde las novelas y las películas nos han aportado quienes crean e innovan en artes. La ciudad es un entorno en constante ebullición. En las ciudades se verifica un intenso encuentro de gentes y diferencias (véanse las películas de Cesc Gay o Kore-eda Hirokazu como ejemplos). La ciudad gestiona los cambios sociales más representativos. Las relaciones humanas adquieren un talante peculiar en el entorno urbano: se intensifican. El apego por lo urbano nos lleva a ver Nueva York con los ojos de Woody Allen, Marsella con la lúcida increpación de Robert Guédiguian, Barcelona a través de la mirada de Ventura Pons, Madrid con el desparpajo de Pedro Almodóvar, París desde el prisma de Éric Rohmer o Roma en tanto que escenario perfecto para el cine de Federico Fellini. Estas ciudades y todas aquellas que conocemos gracias a las películas han tenido igualmente referencias claras en el mundo de la literatura. Baste recordar la Praga retratada por Franz Kafka, el Buenos Aires de Jorge Luis Borges, el Dublín de James Joyce o la Estambul de Orham Pamuk (2009). Acercar al profesorado a las miradas urbanas de los creadores (cineastas, escritores) permite que reflexionen sobre su propia mirada hacia la ciudad. Al mismo tiempo que revisamos brillantes ejemplos del cine y la literatura les animamos a confeccionar sus propias narraciones, tanto en escritura como en imagen. Esta parte de nuestra estrategia consiste en empujar a los docentes a generar documentos propios en los que podamos ver cuál es su particular mirada urbana. Los documentos generados por docentes ofrecen una nueva perspectiva antes invisibilizada. A los textos literarios se añade la fotografía, como la del entorno de grafiteros de La Habana de la figura 1. 


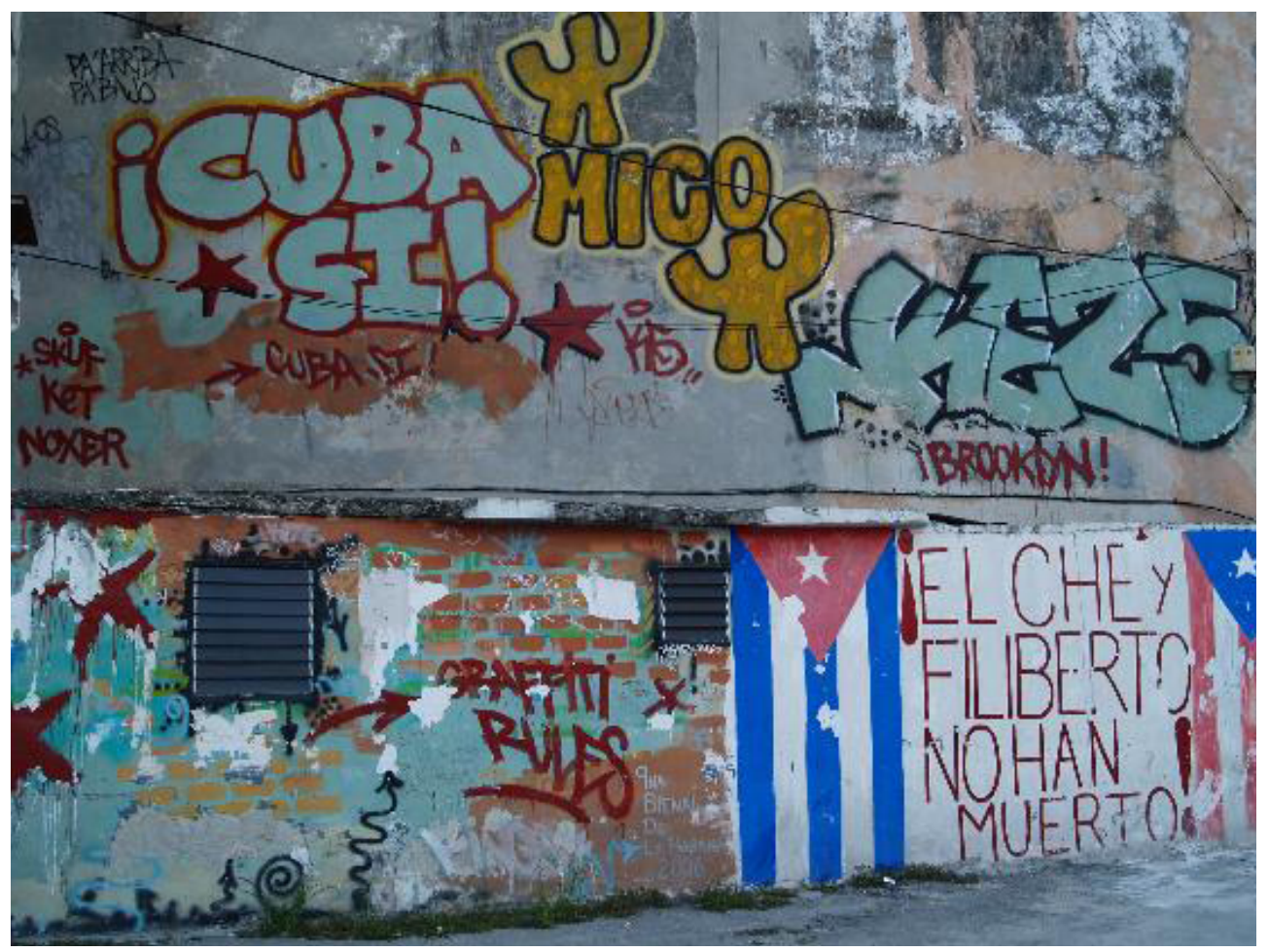

Figura 1. El atractivo visual y patrimonial de La Habana es tan evidente como la necesidad de restaurarlo. Grafitis en un muro de La Habana, Cuba.

Animamos al profesorado a generar su propia imagen de la ciudad a partir de sus textos y sus imágenes. Desarrollamos así una visión del entorno mucho más impregnada de estímulos, lo cual nos encamina hacia a un activismo cultural y político. De este modo posibilitamos que el colectivo docente reflexione sobre lo que está ocurriendo en las actuaciones urbanas recientes, al tiempo que recuperamos los espacios de la memoria, construyendo una mirada particular hacia la ciudad en la que se unen los recuerdos, las presencias, las ausencias, y principalmente un deseo de mejorar los lugares donde vivimos. Con la intención de lograr un modelo identitario, planteamos una metodología que integra ideas desde el arte, la pedagogía, la estética, la cultura visual, la literatura, el cine, la sociología y el urbanismo. A esta intención reflexiva y de calado social añadimos lo que ya se está convirtiendo en un posicionamiento a nivel global: las derivas urbanas tal y como han sido expuestas por Francesco Careri (Careri, 2002) o Gilles Deleuze (Deleuze y Guattari, 2004). Esto supone revisar muchos de los conceptos que se daban por sentado hace escasamente una década. Ya no hay certezas, ni tampoco 
soluciones «desde arriba». La nueva forma de construir la ciudad se basa en un replanteamiento de lo urbano que debe tener en cuenta la opinión de los colectivos implicados. El colectivo docente, entendido como conjunto de personas que nos dedicamos a la docencia, constituye un referente de primera línea dentro de esta perspectiva innovadora y rompedora. Vivimos en la ciudad y somos responsables, también, de cómo se diseñan las políticas urbanas. Si hacemos frente a este reto tenemos muchas posibilidades de mejorar nuestras realidades.

Dentro de este esquema de recuperación de la memoria urbana y de apropiación de los espacios de la ciudad, Francesco Careri recomienda andar por la ciudad, perderse en ella, reencontrarla desde nuevas perspectivas, analizarla y mejorarla en el uso y el disfrute, convirtiéndola en un entorno propicio para la comunicación, y para la justicia social. En una línea similar, Silvia Alderoqui defiende un acercamiento a la ciudad desde posicionamientos sensibles, evidenciando las múltiples sensaciones que provoca el ambiente urbano, de manera muy especial cuando se combina con la memoria y con los recuerdos personales (Alderoqui, 2012). Intentamos vertebrar un encuentro de miradas que propicie reflexiones del profesorado sobre multitud de cuestiones que afectan a la ciudad, con el fin de preparar a la ciudadanía también en el conocimiento y la defensa de sus intereses. Walter Benjamin se deja llevar por los entresijos de la memoria y define las sensaciones que evidencian el paso de los años y la acumulación de experiencias vividas en la ciudad (Benjamin, 2005). Nos transmite con su lenguaje una acumulación de indicios y realidades, algo que permite la vida urbana, al experimentar vivencias que se cruzan con recuerdos y posibilidades de futuro. Llevado al terreno del arte, este concepto podría encajar con el de Marco Romano, quien propone un ejercicio de lectura de la ciudad como si se tratase de una obra de arte (Romano, 2008). Podemos, por tanto, concedernos una lectura de lo urbano muy próxima al modelo de lecturas que elaboramos para las obras de arte. Al mismo tiempo, teniendo en cuenta que somos docentes, merece la pena plantearnos hasta qué punto nuestra mirada hacia lo urbano puede ejercer un cierto mecanismo reflexivo entre nuestro alumnado. 


\section{La reivindicación social y el posicionamiento ideológico como mecanismos educativos}

Jaume Martínez Bonafé repasa las numerosas opciones educativas que posibilita la ciudad desde un posicionamiento de reivindicación social, detectando que la ciudad es también un aula viva en la que se aprende la protesta, al mismo tiempo que la considera un laboratorio de ciudadanía en el que se ensayan posibilidades de encuentro y relación diferentes (Martínez Bonafé, 2014). Al indagar entre las múltiples opciones que se verifican desde la ocupación del espacio público por parte de la ciudadanía, revela que en realidad las protestas ciudadanas y los movimientos sociales que las articulan nacen del conflicto político sobre un modo de entender y querer vivir la ciudad (Donaire, 2012). En la ciudad se dan las más variadas interacciones (más allá del escenario neoliberal o neocapitalista), al tiempo que se propician jugosos procesos de cambio. Cuando nos referimos a la ciudad se suele atender a cuestiones de urbanismo y arquitectura, a desplazamientos y migraciones humanas, a oferta de servicios y estructuras comerciales, o incluso a redes de intercambio que provienen de entornos laborales o ideológicos (Codeluppi, 2014). Pero la ciudad también es un enclave de agitación cultural y de acción política, lo cual repercute en un mayor desarrollo de la lucha por los derechos humanos y de las actividades que evidencian una auténtica innovación en todos los ámbitos de la comunicación humana. La ciudad se escribe, relata su alegato en defensa de nuevas opciones de convivencia y respeto por la diversidad (Guzmán Ríos, 2012). La ciudad es un ente articulado, y puede combinar particularidades muy diferentes. 


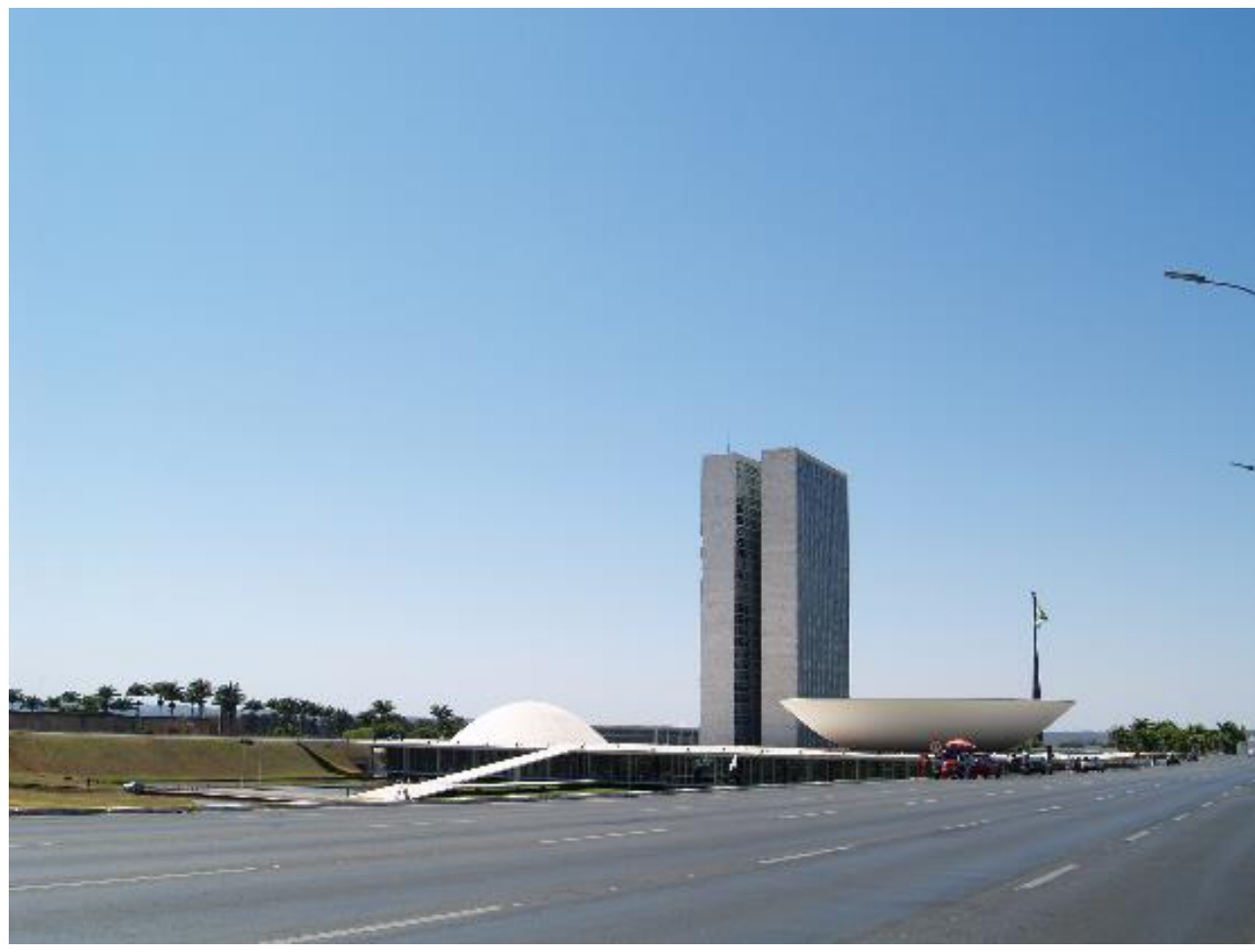

Figura 2. La espectacularidad arquitectónica y urbanística de Brasilia no admite un espacio de las personas. Es una ciudad pensada para las instituciones. Parlamento de Brasilia, Brasil.

El enclave geográfico, la extensión y la posibilidad de expandirse, la llegada de oleadas migratorias, el abastecimiento de agua, o el comportamiento de sus políticos, son factores que tejen la idiosincrasia de cada ciudad (ver figura 2). Como docentes podemos observar y transmitir una mirada urbana en la que predomine la gestión de los derechos humanos. Atender a cuestiones como el derecho a una vivienda digna, el respeto por los espacios públicos, el conocimiento del patrimonio común, el acceso a servicios sanitarios universales, o la defensa de las minorías, son aspectos que podemos transmitir al alumnado. La forma de plantear las recientes investigaciones educativas permite incorporar elementos de las artes y la comunicación al discurso docente. Ahora estamos más receptivos a las imágenes y atentos a las representaciones artísticas contemporáneas. Nos decantamos por la cultura visual, de manera que la reflexión en torno a las imágenes invade y determina buena parte de nuestro repertorio investigador y docente. Se trata de provocar la reflexión, actuando de manera consciente, disfrutando con la actualización de conoci- 
mientos, transmitiendo una mayor implicación, y colaborando con nuestro alumnado (Franco y Huerta, 2011). Motivación y espíritu colaborativo. Estamos en condiciones de formar a los ciudadanos de mañana para favorecer un acercamiento crítico hacia las imágenes y hacia nuestro entorno. Los futuros docentes deben aprender a observar su hábitat y conocer los mecanismos adecuados para crear sus propias fotografías y videos. Pueden formarse como lectores críticos de imágenes, al mismo tiempo que practican y ejercitan su potencial como generadores de un imaginario propio. Todo ello sin descartar una posible y recomendable vertiente lúdica, disfrutando de los artefactos visuales al tener un mayor conocimiento del poder que ejercen las imágenes (Duncum, 2008). Al preparar en las aulas universitarias a los jóvenes docentes estamos ocupándonos indirectamente a la ciudadanía del futuro, mediante la formación de educadores. Confiamos en ellos y en el potencial de cambios y mejoras que atesoran. Si el docente se interesa por las cuestiones que afectan a su alumnado, será muy probable que encuentre espacios de intercambio suficientemente porosos. Apostamos por incentivar dichos intereses, y por encontrar vías comunicativas que faciliten el acercamiento entre el profesorado y el alumnado tanto en la escuela como en la universidad (Huerta, 2015 b).

Si lo que pretendemos es generar una sensibilidad adecuada que propicie un mayor desarrollo de la estética que comunica la ciudad, es necesario implicar tanto al profesorado como al alumnado. Pero también hace falta que desde la administración educativa se tomen las medidas oportunas. Todavía estamos lejos de conseguir un avance significativo, vamos dando pasos en positivo para lograrlo, mientras tanto vamos poniendo en marcha diferentes acciones para desarrollar nuevas ideas. Lo más grave es que al mismo tiempo que generamos investigación y promovemos proyectos desde la educación artística, observamos cómo va desapareciendo la presencia de las artes visuales en los programas oficiales del currículum escolar y universitario. En ese sentido el caso de España llama la atención, ya que mientras en otros países de referencia está aumentando curricularmente el espacio de las artes y la educación artística, aquí se está eliminando a un ritmo vertiginoso. Si esta tendencia continúa, en pocos años podríamos ver que han desaparecido las artes del currículum escolar, y lo que es peor, habrá desaparecido de la educación primaria y secundaria el grueso del profesorado que se encarga de las 
materias de las artes y las humanidades, algo que ya resulta predecible en el entorno universitario (Ordine, 2013).

Nuestro papel como docentes supone estar muy atentos a lo que está ocurriendo ahora mismo en nuestro entorno inmediato, y por supuesto en otras partes que puedan considerarse referencias emergentes y atractivas. Conviene introducir en el aula las problemáticas que afectan a las personas, a los colectivos, y a nuestro propio alumnado. Estas cuestiones forman parte de los valores compartidos ya que «el concepto de patrimonio colectivo favorece también el sentido de cohesión y cooperación así como la creación de redes colaborativas, valores imprescindibles para crear proyectos de inclusión social» (Calbó, Juanola y Valdés, 2011, p. 22). Entre los docentes se puede crear un espíritu colaborativo que tenga en cuenta las cuestiones del arte y del patrimonio, considerando las obras de la cultura artística y arte patrimonial desde una definición abierta y generosa en la que se incluyan todo tipo de artefactos susceptibles de ser valorados estética y culturalmente. Construimos la ciudad desde la ciudadanía, desde los colectivos y los grupos con identidad propia. Los grupos están marcando el empoderamiento desde las redes sociales, y desde los espacios públicos. En el valor de lo cotidiano radica el nuevo potencial creativo de la ciudadanía. A los docentes urbanos nos unen una serie de rituales, sensibilidades y deseos que pueden confluir en una serie de lugares comunes, o al menos de intenciones de mejora, desde donde tantear una aproximación enriquecedora. En ese sentido conviene elaborar una nueva interpretación de los sueños cotidianos y los deseos de mejorar que mueven a los docentes como colectivo, como grupo, como comunidad emocional, como entidad grupal que forma parte de la ciudad.

Al perder predominancia la figura emblemática del individuo toman fuerza el ambiente comunitario y las formas de apreciación y disfrute que parten de lo colaborativo. De este modo se promueve un nuevo paradigma estético que tendrá en cuenta los sentimientos compartidos y el sentir en común del grupo. El acento recae más en aquello que une al grupo que no en aquello que lo puede separar, fortaleciendo de este modo el sentido participativo, generando una estética y una mitología particulares que sirven de receptáculo para gestionar una nueva expresión del sentido que adquiere el concepto «nosotros». 


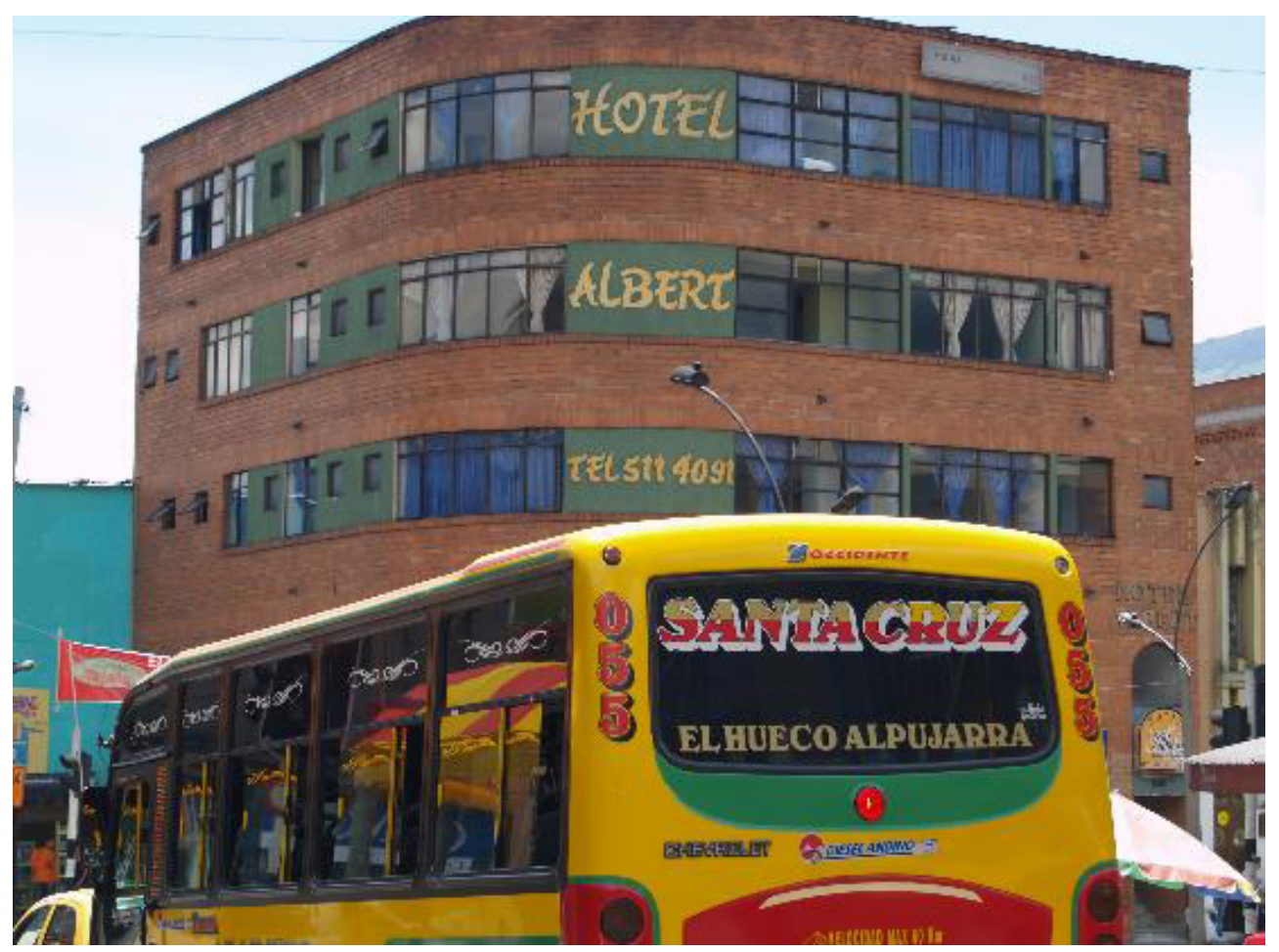

Figura 3. Las encrucijadas de símbolos (arquitectura, urbanismo, señalética) predisponen a la mirada nómada hacia la ciudad. Medellín, Colombia.

El deseo de conservar un bien patrimonial y un entorno humano congrega intereses, más allá de las diferencias de género, clase, religión o posición social (ver figura 3). Esta unión basada en la generosidad y en el respeto hacia los bienes comunes es algo que suele estar entre los intereses del profesorado. El sentido de la responsabilidad y el respeto hacia el bien común constituyen características inherentes al colectivo docente.

Los docentes somos empáticos con las dificultades de los colectivos sociales. Asumimos retos constantemente, ya que nuestras actividades se emplazan en el trato directo con las personas. Nos adaptamos rápidamente a los retos que nos imponen los cambios tecnológicos o los vaivenes económicos. Nuestra unión en tanto que profesionales de la educación conlleva una fuerte componente de sentimientos comunes, lo cual suscita una moral diferenciada, una ética del compromiso, una experiencia compartida. Nos sentimos más unidos cuando se trata de afrontar los problemas desde un planteamiento reivindicativo común. La capacidad de organización del conjunto de los docentes se hace efectiva si se tiene en cuenta que la lucha compartida ha posibilitado 
una costumbre que ha determinado durante décadas el espíritu de lucha del colectivo. Esta herencia es importante. El colectivo se aferra a sus derechos y reclama insistentemente mayores oportunidades. Para lograrlo ejercita una serie de acciones y visibiliza su afán de libertades. Muchas de estas intervenciones tienen lugar en el espacio urbano. Las acciones cotidianas también repercuten en esta posibilidad de visibilidad, ya que cualquier espacio de la ciudad y en cualquier momento se convierte en escenario posible para incentivar la reivindicación y para la celebración de los hábitos comunes. Así pues, la estética como indagación y especulación colectiva revierte en un posicionamiento ético de máxima entidad. En las últimas décadas países como Argentina, Uruguay, Brasil, Chile o España han dado muestras fehacientes del espíritu común que une a los docentes cuando se trata de defender sus derechos o de reclamar mayores oportunidades.

\section{Contrastar las diferentes miradas docentes urbanas entre profesorado de varios países}

En nuestro recorrido por las ciudades y sus docentes intentando descifrar si existe una mirada particular del profesorado hacia la ciudad, nos hemos detenido en realidades tan diversas como las de Buenos Aires, Lima, Montevideo, Santiago de Chile o Valencia. También hemos indagado en otras ciudades como La Habana o Sao Paulo, si bien para este trabajo nos hemos centrado en los datos recogidos de las experiencias de docentes que viven y trabajan en las capitales de Argentina, Perú, Chile y Uruguay. El final de la presente muestra estará dedicado a la ciudad mediterránea de Valencia.

Una metrópoli como Buenos Aires contiene en sí misma un verdadero universo de situaciones particulares. Las distancias económicas y sociales se evidencian en las diferencias que caracterizan cada barrio y cada distrito. El barrio de Liniers, en el que está ubicada la escuela Félix de Olazábal, es una zona limítrofe de la ciudad, un barrio en el que destaca la presencia de mucha gente llegada desde Bolivia. Desde hace más de tres décadas han sido constantes las oleadas migratorias procedentes de Bolivia. En la mayoría de los casos se han instalado mayoritariamente en este barrio. Locales donde se venden desde ropa interior hasta las más variadas especias son atendidos por sus dueños bolivianos. El paisaje urbano de las calles del barrio parece haberse 
transformado en un modelo visual que resultaría muy propio de cualquier ciudad boliviana. Una parte del alumnado de la escuela proviene de familias bolivianas. Para los docentes del centro supone un atractivo y un reto trabajar con la diversidad. Para mejorar la institución educativa se requiere una fuerte toma de contacto con la realidad externa (ver figura 4). Las distintas causas de marginación, política o económica, tan comunes en Latinoamérica, son también los problemas que se viven en la escuela. Las condiciones de pobreza extrema a las que se enfrentan muchos sectores sociales crean problemas que la escuela debe encarar para que la distancia económica no se convierta también en distancia simbólica.

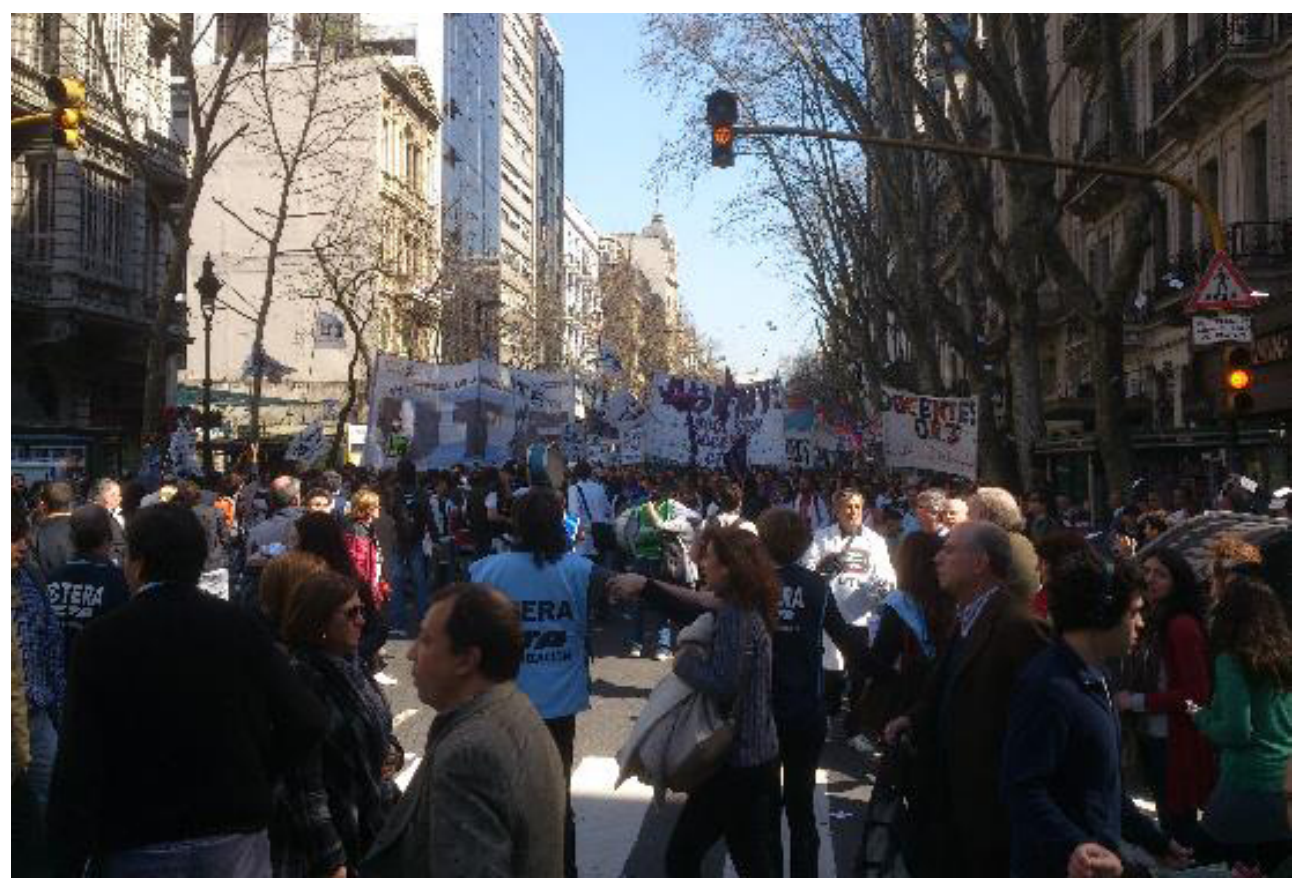

Figura 4. El colectivo docente argentino siempre fue muy combativo, organizando acciones para reclamar sus derechos. Manifestación de docentes en Buenos Aires.

La escuela debe fortalecer su capacidad reflexiva para pensar y ayudar a resolver la problemática que se genera en estos contextos turbulentos y comprometerse activamente para que sus alumnos no queden marginados del sistema ni segmentados dentro de él. Transitamos por un nuevo paradigma de interacción y convivencia social que apunta hacia una visión comprensiva, integradora y humanista. El proyecto planteado por la escuela Félix de Olazábal del barrio de Liniers ofrece al alumnado la oportunidad de ampliar 
el campo estético-expresivo a partir de las diversas propuestas que ofrece la contemporaneidad, trasladando los criterios característicos del arte a la planificación de las actividades de todas las áreas de conocimiento y en las prácticas cotidianas, favoreciendo la formación de su sensibilidad a través del contacto con el entorno sociocultural del barrio y de la ciudad.

Para fomentar entre el alumnado una mirada desprejuiciada y libre hacia lo urbano hemos de fomentar el respeto hacia los espacios públicos, estimular los paseos, conectar con la realidad de la calle, reconocer la diversidad y sus múltiples facetas, aceptar la diferencia. Utilizando el arte como estrategia se pueden alcanzar estos retos (Ramon, 2013), ya que nos permite indagar en territorios complejos desde las imágenes, las interpretaciones y los conceptos (Huerta, 2013). La ciudad es un ámbito complejo, pero nuestras respuestas creativas a dicha complejidad pueden evolucionar positivamente si somos capaces de superar complejos y miedos. Verónica, una maestra que trabaja con adolescentes de secundaria, llegó a Buenos Aires hace diez años, procedente del entorno rural, y detectó inmediatamente el gran cambio que había tanto en la forma de educar como en el comportamiento de los adolescentes. A esta profesora de ciencias sociales, formada como abogada, le gusta plantear dudas entre el alumnado de manera que sean capaces de argumentar para resolver sus conflictos. Ve la ciudad como un lugar interesante para hacer visitas y fomentar la parte cultural, yendo al teatro y al cine, e invitando a gente del teatro para dar charlas. Lleva a su alumnado a los museos. Lucía, profesora de lengua, viaja todos los días en tren, en metro y en autobús para llegar a su puesto de trabajo, en trayectos de más de una hora. Le encanta mantener una relación estrecha con el alumnado adolescente, algo que echó en falta cuando ella misma estudió la secundaria. Uno de los proyectos en los que se ha implicado se titula «Perfeccionamiento lingüístico a partir de una obra de arte». Organiza visitas al Museo de Bellas Artes, habladas en francés, tratando especialmente la pintura de los impresionistas. Lucía cree que el hecho de ser educadora en una ciudad con tanto potencial cultural como Buenos Aires es muy enriquecedor, para los docentes y para el alumnado.

Pablo Pineau es profesor de historia de la educación en la Universidad de Buenos Aires. Siempre se ha sentido muy atraído por las cuestiones sociales, desde el final de la dictadura, cuando cursaba sus estudios superiores. La 
apuesta por la educación significa para él la clave del cambio social. Se siente afortunado al trabajar formando a futuros maestros en una Escuela Normal, y orgulloso de haber creado junto a sus alumnos el archivo histórico de la facultad de educación de la UBA, en su sede de Luján. Le gusta la ciudad, y piensa que la universidad pública marca los ritmos, ya que forma parte esencial del espacio urbano, especialmente para la mayoría de sectores culturales y sociales. Se encuentra explorando la historia de la educación desde la vertiente creativa, escribiendo textos literarios que son ilustrados por colegas artistas, y reclama una vertiente que denomina «estética escolar», para acercarse a los medios de comunicación y a las artes desde posicionamientos educativos. Marcela Pelanda, rectora de la Escuela Normal No 1 de la ciudad de Buenos Aires, se formó como maestra y se considera muy afortunada de «entregarse cada día a los otros». Ha ejercido la docencia en todos los niveles. Coordina una escuela de 3000 alumnos, uno de los centros más importantes de la ciudad, y es consciente de que los modelos actuales están limitados ante los profundos cambios que se viven. Su desafío supone lograr una nueva escuela en la que profesorado y alumnado trabajen juntos. Considera que debemos ganarnos el respeto y la autoridad ante cada alumno, y con ganas renovadas cada curso. Marcela fomenta encuentros para reivindicar la memoria de la dictadura, «uno de los hechos más tristes de la historia Argentina», y piensa que esta y otras tantas actividades sirven para generar proyectos de futuro, como un desafío que avanza en paralelo a con la profesión. Considera fundamental la formación de maestros para llevar adelante una necesaria innovación en el panorama educativo.

Los y las docentes bonaerenses definen su ciudad como «expandida, injusta, desigual, abierta, intensa, estimulante inmensa, infinita, nostálgica y luminosa». «Una ciudad donde la amistad se cultiva como un valor supremo». «Es el reflejo de una historia compleja, de la lucha de intereses y valores, de quienes vivieron y vivimos en ella». Encuentran arduo «tener que transitarla diariamente» ya que «tiene un ritmo de locos, acelerado, vertiginoso». Se quejan de que «las políticas de derecha del gobierno de la ciudad han desmontado sus redes de solidaridad y asistencia institucional». Al definir un lugar que les resulte especialmente atractivo aparecen «las callecitas adoquinadas del barrio de San Telmo». Como entornos patrimoniales de referencia señalan el Centro Clandestino de detención durante la última dictadura mili- 
tar, convertido hoy en un espacio para la memoria que albergan además los canales de Televisión Educativa Encuentro y Paka Paka. También destacan la Biblioteca Nacional de Clorindo Testa o el Edificio del Pasaje Barolo, aunque hay quienes prefieren «el antiguo puerto, el bar de la calle Rodney, o la Pizzería Angelín con amigos». Nos dicen que «enseñar Buenos Aires propicia habitarla de manera reflexiva y emocional a la vez, e implica también luchar para que siga existiendo como un lugar para todos». Entienden que «es necesario detenerse, mirarla y conocerla para disfrutarla», ya que «Buenos Aires se habita en un fluir de hábitos y pasos apurados casi irreflexivos». Existe una preocupación constante por la educación de y en el espacio público, de manera que en las clases se reflexiona sobre la importancia, la construcción y el ejercicio de ciudadanía. Se problematiza la realidad, planteando interrogantes, promoviendo que los estudiantes se sientan habilitados para expresar sus ideas, generando debate, estimulándoles a que escuchen las distintas voces. De este modo «producimos subjetividad común, fundamental en la búsqueda de un nuevo sentido institucional», más aun teniendo en cuenta «la crisis profunda que el neoliberalismo dejó en Argentina, no sólo en lo económico sino también en lo simbólico».

Lima, la capital del Perú, transmite la sensación de caos. El tráfico resulta atronador e imposible, debido en parte a no disponer de un sistema municipal de transporte público organizado, lo cual provoca situaciones de peligro. En Lima encontramos muy acentuadas las diferencias entre estamentos sociales. Barrios como Miraflores o Barranco se convierten en entornos habitados por las clases altas, mientras que la mayoría sucumbe a un manifiesto deterioro en el nivel de vida. Estas mismas delimitaciones que marcan los espacios urbanos podemos encontrarlas en los entornos públicos como las escuelas o los hospitales. En Lima numerosos edificios están sin terminar, lo cual se debe en parte a la situación económica, pero también al peligro constante de movimientos sísmicos. En los últimos años se está potenciando la construcción de edificios de excesivas alturas, algo difícil de entender en una zona de alto nivel sísmico. El miedo a los terremotos, a la inflación de la moneda y a las crisis constantes, así como el terror a lo que fueron las luchas entre la guerrilla y el ejército, se unen aquí para presentarnos un paisaje en el que domina la búsqueda de seguridad como moneda de cambio. Tanto el caos de la circulación, como la polución ambiental y sonora, así como el miedo 
a la delincuencia, han convertido Lima en un lugar poco atractivo para los turistas, que utilizan la ciudad como escala para trasladarse a lugares Machu Picchu o Cuzco. La tradición artesana de los tejidos constituye uno de los tesoros de su cultura.

Las docentes limeñas que definiesen su ciudad como «gris, húmeda, nublada o deprimente». El aspecto gris de la ciudad está íntimamente relacionado con los meses de invierno en que la capital permanece completamente nublada gran parte del tiempo. Se valora asimismo la tradición, que se emparenta con la comida, la diversidad, la historia, la fusión, la complejidad y la originalidad. Se revela un contraste entre la parte acogedora (bonita, cordial, antigua, única, emprendedora, divertida, interesante, inmensa) y la contraparte desordenada (ruidosa, caótica, insegura, ruidosa, contaminada). Se valora la oferta cultural y la gastronomía, enlazando con la fama mundial que ha adquirido la cocina peruana de fusión. Algunas la consideran única, evidenciando la gran oferta comercial y el movimiento constante. Se hace mención a los vendedores ambulantes, un elemento peculiar que sigue muy vigente en las calles limeñas.

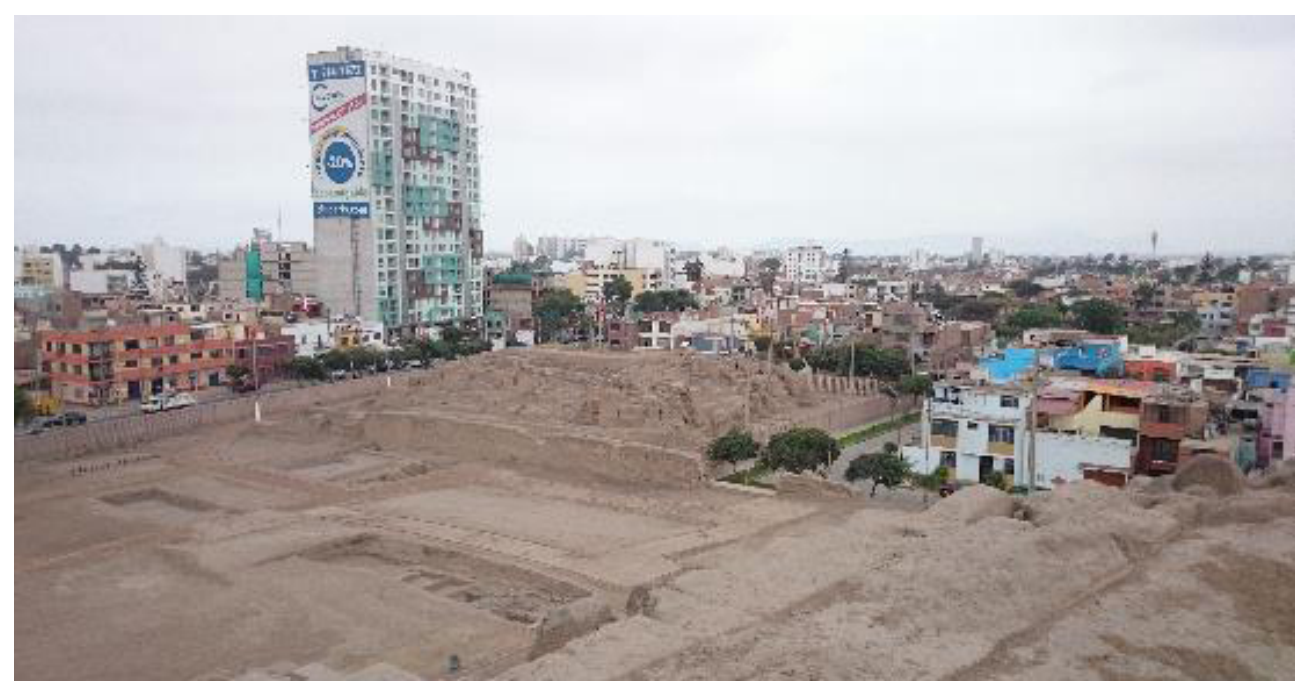

Figura 5. Lima dispone de 600 recintos arqueológicos, muchos de ellos pendientes de recuperar y conservar. Huacas de Mateo Salado (cultura Ichma) en Lima, Perú. 
A las docentes limeñas les gusta la parte rústica de Barranco, con su Puente de los Suspiros, y la Plaza de Armas, en el centro histórico de la ciudad, así como el Parque de las Aguas, la Punta, la bahía, la Costa Verde, el Parque de la Reserva con su Circuito Mágico del Agua, el Olivar y el malecón de San Isidro, y el centro comercial Larcomar. Entre los lugares patrimoniales que aparecen en sus comentarios destacan la huaca Pucllana, la huaca Pachacámac, y el complejo arqueológico Maranga, como escenarios de las culturas preincaicas (ver figura 5), mientras que la catedral de Lima, el palacio Arzobispal y la Iglesia de San Francisco (con sus catacumbas) serían los elementos patrimoniales más citados del repertorio religioso católico. Insisten en la inseguridad, ya que «en la zona que me muevo no se puede caminar tranquila sin estar atenta a quienes te rodean, pues se vive con el miedo de ser violentada, asaltada o a cualquier otro tipo de agresión». Frente a esta sensación de inseguridad, resultado de muchos años de malas prácticas ejercidas desde el poder, las palabras de Noelia apunta a que se vive «una sensación de mejora, ya que por más cosas negativas que ha tenido que pasar nuestra sociedad, siempre hemos querido salir adelante, luchando para mejorar como sociedad y crecer como país», o en el caso de Rosa, quien siente «deseo de superación o de un cambio para mejorarla», y considera que «Lima tiene aún mucho que ofrecer al mundo, lo cual me genera ganas de ser parte del cambio que necesita».

Al preguntarles hasta qué punto consideran importante asumir la pertenencia al colectivo de docentes para generar una identidad propia como grupo, responden afirmativamente, «ya que los docentes generamos un cambio en la sociedad mediante la educación», como en el caso de Belén, para quien «la educación es una tarea de todos y no solo de unos cuantos docentes». Camila opina que «los docentes son parte importante en la formación ciudadana». Carola ve necesario que el docente «se centre en los diversos grupos y clases sociales, ya que todos los peruanos debemos conocer los lugares donde vivimos», mientras que Dominique considera importante «el sentido de pertenencia para un trabajo docente en grupo». Maki cree que «es necesario saber que se forma parte de un colectivo».

Montevideo, capital de Uruguay, sigue una larga tradición por la lucha de los derechos sociales, algo de lo que puede estar orgullosa esta pequeña repú- 
blica, pionera en la reglamentación a favor del divorcio o del voto femenino durante el siglo xx, y ya en el presente siglo continuando dicha tradición legislando de forma favorable al matrimonio igualitario y a los derechos humanos a través de las políticas contra la homofobia y de apoyo a las minorías LGTB. Se puede afirmar que Uruguay es un país donde la educación es realmente laica, universal y gratuita. La preocupación por las cuestiones educativas y sociales se vive de forma muy intensa en esta república de pocos contrastes, un país tranquilo, con tradición democrática, uno de los ejemplos más entusiastas de concordia civil en el panorama histórico de América Latina, ensuciada solamente por una dictadura que se prolongó desde el golpe militar de 1973 hasta 1985. La responsabilidad de formar a la ciudadanía en base a una actitud respetuosa hacia la diversidad (Huerta y Alonso, 2015) y los patrimonios (Huerta y Calle, 2013) estimula los ánimos para llevar adelante acciones $\mathrm{y}$ proyectos de futuro.

Al definir Montevideo los docentes uruguayos utilizan la expresión «tranquilidad». En efecto, la capital y el resto del país son lugares tranquilos. Según el colectivo docente se trata de una ciudad tremendamente «acogedora, amigable, hospitalaria, hermosa, amable, abierta, y luminosa». También insisten en que es «pequeña». Sus dos millones de habitantes se expanden por amplios espacios y se confunden con un paisaje monótonamente plano. Una docente la representa de un modo más poético: «ciudad de mar». Montevideo siempre fue una ciudad muy pendiente del mar, con su puerto natural, tan apreciado por su posición privilegiada, su fortaleza y su papel estratégico en el Mar del Plata. Con sus vientos intempestivos, que en los meses de invierno hielan el ambiente, la definen con las palabras «viento, frío, sombra», y con su «monocromática» austeridad, debido a la predominancia de nubes grises durante el período invernal. Algunos docentes inciden en que es «inquieta» o «pintoresca», y que está «llena de oportunidades», refiriéndose a la rica oferta cultural. Los docentes uruguayos tienen clarísimos referentes en cuanto a preferencias artísticas si se trata de generar mitologías urbanas. Prácticamente todos los encuestados han optado por señalar a Mario Benedetti como el escritor por excelencia de la ciudad, si bien el literato tuvo que exiliarse a la fuerza, y optó por el autoexilio cuando terminó la dictadura. Es un personaje muy querido, y tanto su prosa como su poesía se mantienen extraor- 
dinariamente vivas y siguen siendo las preferidas de varias generaciones de profesores.

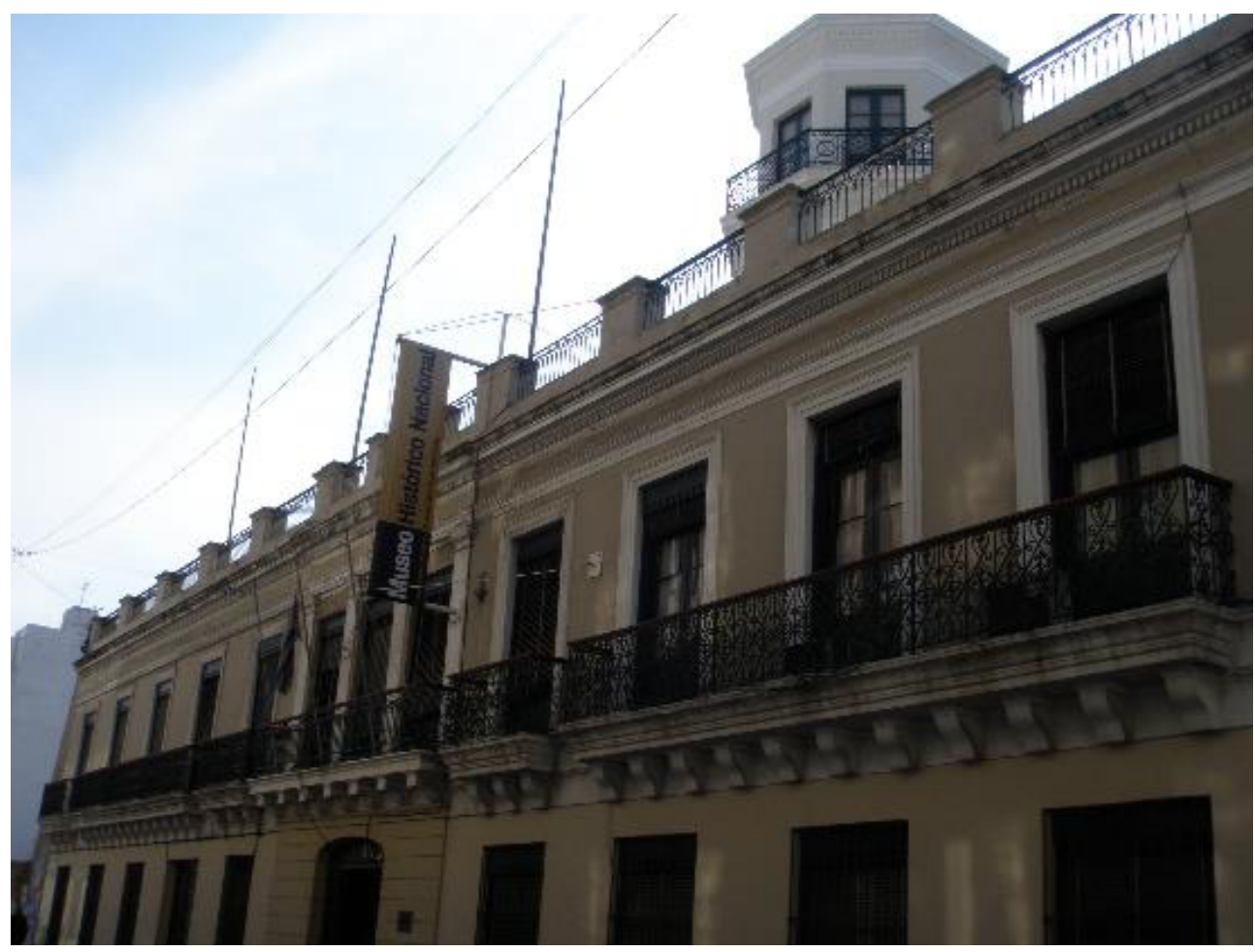

\section{Figura 6. El centro histórico de Montevideo (Uruguay) mantiene antiguas casonas convertidas en museos, con historias rocambolescas utilizadas por el profesorado en sus visitas.}

Al preguntarle a los docentes sobre un lugar de Montevideo que les resulte especialmente atractivo coinciden en indicar la Rambla del Parque Rodó. Algunos prefieren la Ciudad Vieja (ver figura 6), o el Palacio Legislativo. Una profesora destaca la panorámica desde el Cerro. El Hipódromo de Maroñas es símbolo patrimonial. Se detecta el respeto a ciertos edificios más emblemáticos, como el Palacio Salvo o la casa central del Banco de la República, el Teatro Solís, el edificio de Mercosur, o el Museo de Artes Decorativas, declarado Monumento Histórico. El sentido de pertenencia es fuerte. Una docente lo explica: «a pesar de que hay robos y que a mí me ha sucedido, igual siento que es una ciudad tranquila». La calidez como referencia a lo humano, a la cercanía de las personas: «creo que mucha gente conserva una calidez especial, es amigable sobre todo con el que viene de afuera». Algunos docentes consideran que la energía de la capital se halla en la alegría de sus habitantes: 
«Montevideo me provoca alegría, distracción, despeje mental, deseos de vivir y sentir. Es una sensación especial caminar por su rambla: “Al ver el mar, la arena, las gaviotas, caminar por la orilla, se te despiertan todos los sentidos". Las docentes uruguayas destacan «la importancia de una buena convivencia», pero también inciden en que «los docentes debemos enseñar a participar en la discusión y negociación de los valores que constituyen una sociedad democrática, formar ciudadanos responsables, respetuosos de las diferencias, con normas de convivencias claras, críticos, situados y con conocimiento de los derechos humanos». Se considera «muy importante crear las identidades en forma colectiva, puesto que el colectivo indica muchas veces el rumbo, define la identidad y la sostiene».

En Uruguay consideran que el profesorado tiene un papel sumamente importante, ya que «corresponde a los fines de la educación formar seres autónomos, críticos». Una docente valora que «el sentido de pertenencia a un grupo genera lazos, promoviendo sinergias que fortalecen, consolidan su identidad y perpetúan la razón de ser del colectivo». Se considera fundamental el rol docente «en la permanente reflexión colectiva del sentido de nuestra función como educadores», y «más allá de los contenidos curriculares, debemos aportar espacios de discusión y diálogo crítico en torno a la libertad, los valores y las normas, para la creación de una sociedad plural, solidaria, democrática, comprometida con el medio natural y social».

La cordillera delimita el paisaje visual de Santiago de Chile, ubicada en el centro de un extenso país recorrido de norte a sur tanto por el océano Pacífico como por los Andes. La historia reciente de Santiago y contiene una tremenda mancha de sangre y de dolor debido al lamentable suceso histórico provocado por la cruel dictadura de Pinochet. El territorio y la historia se dan aquí la mano (ver figura 7) para alentar a las jóvenes generaciones a mejorar y a seguir luchando por sus derechos. Las políticas económicas y urbanísticas neoliberales han abierto nuevas y mayores brechas sociales que se unen a las que ya existían anteriormente. El panorama administrativo que rige en la enseñanza también arrastra problemas tradicionales, ya que en este país las escuelas y los institutos de secundaria, es decir los centros de educación obligatoria, están gestionados por las autoridades municipales. A todo ello se suma el descalabro académico a nivel universitario, con una cartera de 
universidades privadas exagerada y oportunista que insiste, una vez más, en marcar las desigualdades entre la población. A pesar de todo, Chile mantiene un acelerado y entusiasta proceso de modernización (Errázuriz, 2015). La docente Marlen, que define Santiago como pujante y exigente, recuerda que la ciudad «tiene muchas áreas verdes y varios rincones chispeantes de vida cultural, a pesar de que no le gusta «el aire sucio y la destrucción de la naturaleza por causa del progreso, o del descuido de quienes creen impulsar el progreso». De la calidad humana de sus habitantes y del aprecio que siento por sus docentes he dado cuenta en anteriores trabajos (Huerta, 2012). En Chile son los estudiantes quienes han dado un ejemplo de coherencia y solidaridad en sus permanentes acciones de protesta, como la conocida «revolución pingüina».

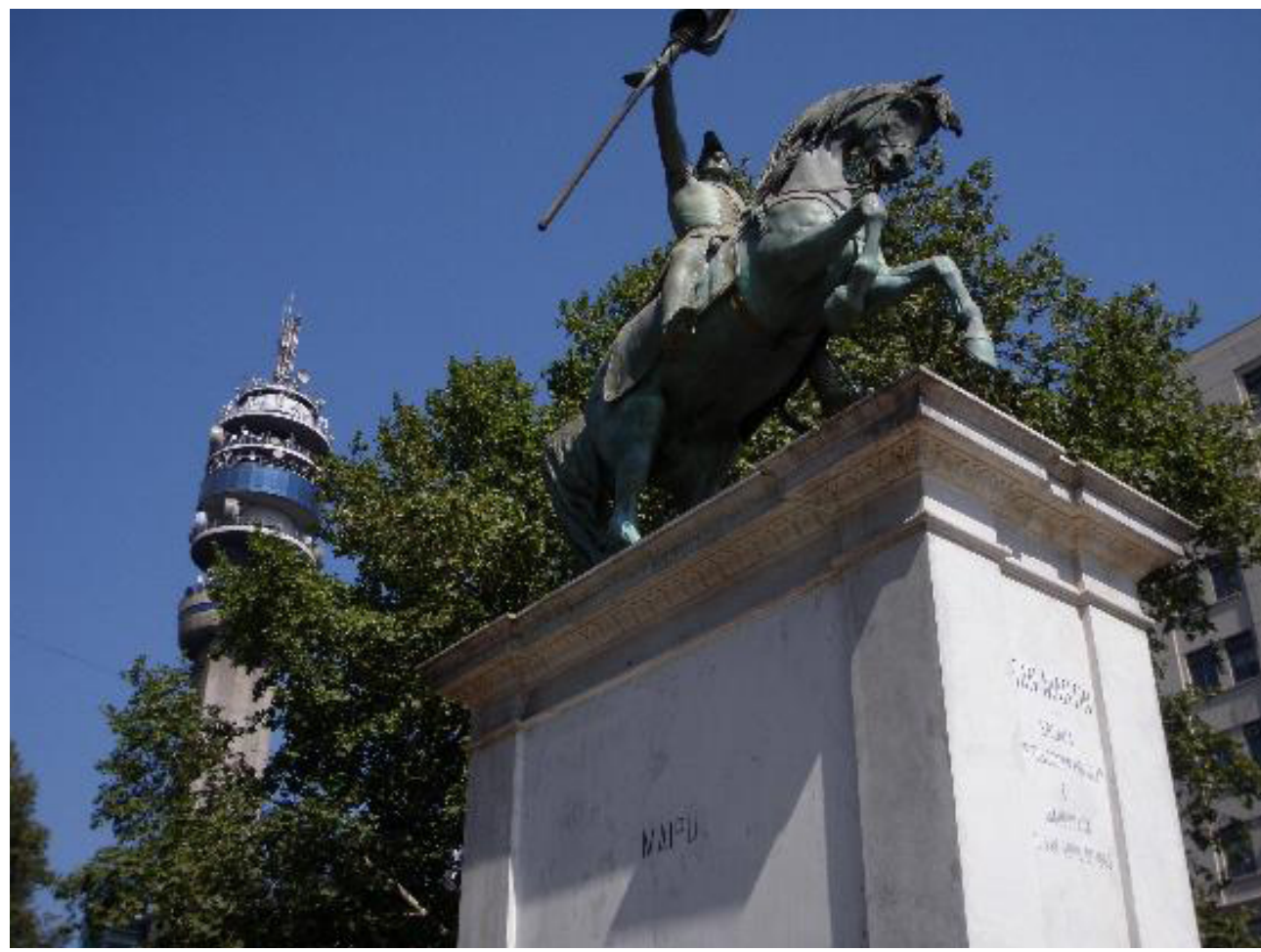

Figura 7. Las esculturas ecuestres de próceres históricos son habituales en los lugares emblemáticos de las ciudades de Iberoamérica. Santiago de Chile.

Lourdes ve Santiago como «una ciudad humana, cercana y acogedora, en la que sin embargo considera que hay escasez de zonas verdes, de carriles bici y de recursos culturales bien aprovechados». Por su parte Marcela encuentra 
que «la ciudad es agradable en verano», y siente «pasión por la cordillera», si bien remarca que «hay demasiada congestión vehicular, poco respeto por el patrimonio, y un exceso de diferencias sociales». Queda claro que la ciudad, y en general lo urbano, constituyen geografías universales, pero evidentemente generan elementos particulares en cada territorio. Para Matilde los aspectos más positivos de la ciudad se resumen en que «está rodeada por la cordillera, por la grandiosidad de los andes, y que resulta muy peculiar el saludo y la despedida como parte de la idiosincrasia de sus habitantes», y añade que en realidad «es cuatro ciudades en un mismo año, ya que las estaciones se manifiestan muy en su esencia». Señala como aspectos que no le gustan que «la contaminación se aceptó y nos acostumbramos a no tener aire», que «hay un exceso de autos y falta de parques», y que «no hubo ni hay un diseño urbano para el bien colectivo y territorial».

\section{Definir la ciudad como patrimonio docente}

En este último apartado, que abordo como posible conclusión, se sugiere la oportunidad de definir el entorno urbano como un patrimonio que puede ser interpretado por el profesorado, mediante sus opiniones sobre la ciudad en la que trabajan o viven. Tanto sus textos como sus imágenes nos aportan una serie de informaciones valiosas sobre su peculiar mirada hacia lo urbano. Observamos cómo articulan su discurso, cómo definen los lugares que les atraen, cómo intentan describir aquello que realmente les preocupa. Nos transmiten sus preocupaciones y sus deseos, así como la sana intención de formar ciudadanía crítica con un espíritu democrático.

En Valencia, entorno que conozco por cercanía y por implicación, he recogido encuestas y documentación de docentes con años de experiencia, así como opiniones de alumnado universitario que está realizando sus estudios de Magisterio. Analizar a estos dos colectivos nos permite contrastar las versiones de docentes experimentados y de docentes en su momento de preparación universitaria. Al fomentar planteamientos participativos, los resultados permiten un encuentro con la mirada (Csikszentmihalyi, 1990), un entorno que favorece la reflexión (Huerta, 2010 b) e incluso un vibrante espacio de actividad y de pulso con el poder, propiciando un encuentro con el arte público y los procesos comunitarios. 


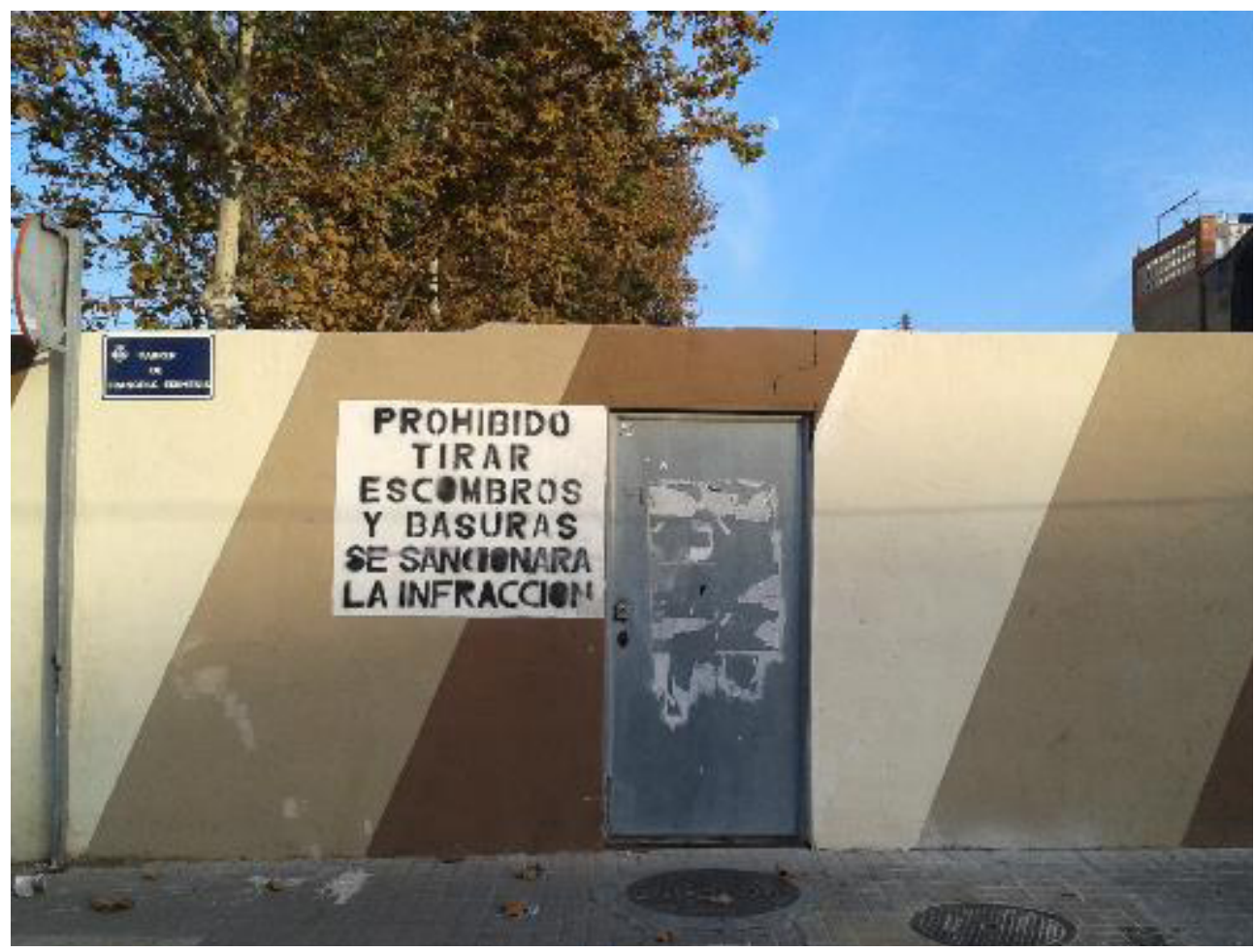

Figura 8. Durante más de dos décadas, el anterior equipo de gobierno del consistorio valenciano destruyó sistemáticamente el entramado urbano del barrio marítimo del Cabanyal. Las franjas diagonales marcaban los solares de antiguos edificios, hoy derruidos.

A Valencia le ocurre algo similar a lo que encontramos en tantas ciudades (ver figura 8), y que denuncia Richard Sennett cuando afirma que «gran parte de la planificación urbana del siglo xx respondía a este principio: derriba todo lo que puedas, arrásalo y luego construye a partir de cero» (Sennett, 2013: 263). Sennett defiende la idea de que el trabajo bien hecho, en cualquier disciplina, produce una satisfacción de gran calado en el profesional consciente de ello. El trabajo planteado y resuelto desde la exigencia nos ayuda a reflexionar sobre nuestra identidad. Para Sennett existe una cierta obsesión de la modernidad por destruir lo que había anteriormente, por ello defiende la postura de los profesionales conscientes de su trabajo a quienes denomina «artesanos». Sennett pide al artesano que apueste por el respeto y la implicación personal. En nuestro caso, como docentes, somos responsables del engranaje educativo de nuestra sociedad. Por eso intentamos conocer qué tipologías de miradas 
hacia lo urbano generan los educadores, y en última instancia, saber si realmente se sienten involucrados como colectivo y como participantes activos del desarrollo de la ciudad (Palacios, 2011).

Observamos de qué manera ven Valencia sus docentes y les preguntamos cómo abordan el tema urbano desde su postura como educadores. Somos conscientes de que tanto la ciudad como lo urbano constituyen geografías universales, pero disponen de elementos particulares en cada territorio. Las encuestas han sido contestadas por una parte de quienes se implicaron en las acciones. Disponemos de 17 encuestas contestadas por educadores valencianos con experiencia laboral. Veremos que son muchas más las recogidas entre el alumnado de Magisterio, manteniendo el anonimato de los participantes y asignándoles un nombre ficticio. Tanto en la preparación de las sesiones como en la elaboración de los cuestionarios seguimos los pasos metodológicos de la interdisciplinariedad, con la educación artística como entorno fronterizo de acción, utilizando referencias a campos como la sociología, el urbanismo o la antropología. La presencia de acciones performativas así como la incidencia en el proceso, convierten este trabajo en una acción colaborativa, ya que la participación de los implicados es una de las claves del compromiso (Ramon, 2015). Lo urbano es complejo, y la forma de acercarse a la mirada docente hacia la ciudad no puede reducirse a una única datación escrita. Una metodología híbrida supone una gran implicación por parte del investigador promotor y de todos los participantes.

El imaginario que nos transmite el profesorado valenciano en los cuestionarios recogidos está impregnado de espacios seductores que mapean la ciudad, cuyos atractivos son muchos (Smith-Shank y Soganci, 2011). La docente Loli la define como «luz, cálida, llana», y si los tres aspectos que más le gustan son «clima, huerta, comida», los que no le gustan son «gobierno, cultura, inundaciones». No detectamos unanimidad al pedir a los docentes que describan aspectos destacables de Valencia, de manera que aparecen tanto espacios naturales como elementos arquitectónicos o urbanos: para Darío «el paseo marítimo, su amplitud, el olor del mar y la tranquilidad que ofrece»; para Fran «la Malvarrosa a primera hora de la mañana con suave brisa de levante»; según Juan «el barrio costero del Cabañal»; para Rosa y Ana «el río Turia» y 
«el antiguo cauce del Turia, reconvertido en parque verde que recorre toda la ciudad»; para María «la Albufera, humedal costero de gran belleza con aves acuáticas»; según Ramón «la zona norte, donde se vislumbra el espacio de la huerta» mientras que para Amparo es «el parque Gulliver», Álex prefiere «la plaza de la Virgen» y Blanca «el rincón de la fuente de José Capuz en la Alamenda»; David habla del «barrio del Carmen», Lucía de «la Lonja», Julián de «la actividad comercial de un domingo en la Plaza Redonda», Pablo del «Mercado Central» y Pepe de «la plaza de San Nicolás»; sin embargo Regina prefiere «los Jardines de Monforte». La multiplicidad de opciones describe también un cierto carácter abigarrado que identifica a lo valenciano (Nava, 2014), muestra del cual podrían ser los trajes de fallera o la fiesta de las fallas, con un aliento estético barroquizante.

Las fotografías que he seleccionado para el artículo las he realizado yo mismo. Habitualmente, en este tipo de trabajos incorporo imágenes hechas por el profesorado a quien he entrevistado, pero en esta ocasión he optado por elegir fotografías mías. Estas fotos no pretenden ilustrar el texto, sino que lo acompañan y lo refuerzan, de hecho, adquieren significado por ellas mismas, como documento visual (Berger, 1980). Se trata de recoger, mediante las fotografías, una visión particular de cómo observa y registra la ciudad un docente, que en esta ocasión soy yo. Al incorporar estas imágenes incluyo la Arts Based Research, ya que mi labor como creador está vinculada con la fotografía y el grabado. Las imágenes dicen tanto sobre las ciudades que interpreto como el texto con las opiniones recogidas de profesores y profesoras de varios países. Por tanto, mi opinión sobre la mirada docente hacia lo urbano ha quedado reflejada, también, en las imágenes aportadas de las ciudades fotografiadas. Al fin y al cabo soy un docente que trabaja y vive en la ciudad. 


\section{Referencias}

Aguirre, I. (2004): «Beyond the Understanding of Visual Culture: A Pragmatist Approach to Aesthetic Education», International Journal of Art \& Design Education, 23 (3), 256-269.

Alderoqui, S. (2012): Paseos urbanos. El arte de caminar como práctica pedagógica, Lugar Editorial, Buenos Aires.

Belil, M., BorJa, J. y Corti, M. (eds.) (2012): Ciudades, una ecuación imposible, Icaria, Barcelona.

Benjamin, W. (2005): Libro de los pasajes, Akal, Madrid.

Berger, J. (1980): Modos de ver, Gustavo Gili, Barcelona.

Braudel, F. (1979): Civilisation matérielle, économie et capitalisme, XVe-XVIIIe siècle. Vol. I. Les structures du quotidien : le possible et l'impossible, Armand Colin, Paris.

Calbó, M., Juanola, R. y Vallés, J. (2011): Visiones interdisciplinarias en educación del patrimonio: artes, culturas, ambientes, Documenta Universitaria, Girona.

Careri, F. (2002): Walkscapes. El andar como práctica estética, Gustavo Gili, Barcelona.

CodelupPI, V. (2014): Metropoli e luoghi del consumo, Mimesi, Milano.

Csikzentminalyi, M. (1990): The Art of Seeing. An Interpretation of the Aesthetic Encounter. Paul Getty Trust, California.

Deleuze, G. y Guattari, F. (2004): Mil mesetas. Capitalismo y esquizofrenia, Pre-Textos, Valencia.

Dewey, J. (1969): Democracy and Education, Macmillan, New York.

DonaIRE, R. (2012): Los docentes en el siglo XXI: ¿Empobrecidos o proletarizados?, Siglo XXI Editores, Buenos Aires.

Duncum, P. (2008): «Holding Aesthetics and Ideology in Tension», Studies in Art Education, 49 (2), 122-135.

Errázuriz, L. H. (ed.) (2015): El (f)actor invisible. Estética cotidiana y cultura visual en espacios escolares, Consejo Nacional de la Cultura y las Artes, Santiago de Chile.

Franco, C. y Huerta, R. (2011): «La creación de una mirada urbana. La ciudad de Santiago de Compostela interpretada por el alumnado de magisterio», Educatio Siglo XXI, 29 (2), 229-246.

Giroux, H. (1990): Los profesores como intelectuales. Hacia una pedagogía crítica del aprendizaje, Paidós, Barcelona. 
- (2013) «When Schools Become Dead Zones of the Imagination: A Critical Pedagogy Manifesto», Truthout, http://www.truth-out.org/opinion/item/18133-when-schools-become-dead-zones-of-the-imagination-a-critical-pedagogy-manifesto [consulta: 13/09/2015]

Guzmán Ríos, V. (2012): «En busca del arte perdido de vivir la ciudad. Experiencia estética infantil en la plaza de Tlalpan», URBS Revista de Estudios Urbanos y Ciencias Sociales, 2 (2), 77-91.

Hernández, F. (2000): Educación y cultura visual, Barcelona, Octaedro.

Huerta, R. (2010 a): «I Like Cities; Do You Like Letters? Introducing Urban Typography in Art Education», International Journal of Art \& Design Education, 29 (1), 72-81.

- (2010 b): «Un proyecto de investigación en educación artística: aspectos identitarios de las maestras chilenas», Pulso, 33, 31-59.

- (2011): Ciudadana letra, Institució Alfons el Magnànim, Valencia.

- (2012): Mujeres maestras. Identidades docentes en Iberoamérica, Graó, Barcelona.

— (2013): «Docentes paseando por las letras de la ciudad», Arteterapia: Papeles de arteterapia y educación artística para la inclusión social, 8, pp. 123-136.

- (2015 a): La ciudad y sus docentes. Miradas desde el arte y la educación, uOC, Barcelona.

- (2015 b): «Desarrollo de ciudadanía desde la educación artística y patrimonial. Identidades urbanas en Iberoamérica», Aisthesis, 58, pp. 197-220.

Huerta, R. y Alonso-Sanz, A. (eds.) (2015): Educación artística y diversidad sexual, puv, Valencia.

Huerta, R. y Calle, R. (eds.) (2013): Patrimonios migrantes, puv, Valencia.

Irwin, R. (2013): «Becoming A/r/tography», Studies in Art Education: A Journal of Issues and Research, 54 (3), 198-215.

— y O'Donoghue, D. (2012): «Encountering Pedagogy trough Relational Art Practices», International Journal of Art \& Design Education, 31 (3), pp. 221-236.

LEOPARDI, G. (2014): Questa città che non finisce mai, Utet, Novara.

LYNCH, K. (1998): La imagen de la ciudad, Gustavo Gili, Barcelona.

Martínez Bonafé, J. (2014): «La ciudad como contenido del curriculum», Cuadernos de Pedagogia, 447, pp. 81-83. 
Nava, A. (2014) Arte cotidiano. La experiencia estética en los recorridos urbanos. Caso práctico: los puentes del río Turia, Valencia. Trabajo del Diploma Educación Artística y Gestión de Museos. Universitat de València.

Ordine, N. (2013): La utilidad de lo inútil, El Acantilado, Barcelona.

Palacios, A. (2011): La comprensión del entorno construido desde la educación artística. Una propuesta para educación primaria y formación inicial del profesorado, Tesis doctoral, Universidad Complutense de Madrid.

Pamuk, O. (2009): Estambul. Ciudad y recuerdos, Barcelona, Mondadori.

Ramon Camps, R. (2013): «Estéticas del entorno urbano: la experiencia de visualización de la ciudad», Revista Matéria-Prima, 1 (2), 98-106.

- (2015) «Reinventar la ciudad, desarrollo de las competencias básicas a través de un proyecto de creación urbana», Revista Matéria-Prima, 3 (2), pp. 79-88.

Sennett, R. (2013): El artesano, Anagrama, Barcelona.

Smith-Shank, D. L. y Soganci, I. O. (2011): «The city as a site for interdisciplinary teaching and learning», International Journal of Education through Art, 7 (1), 27-40. 
